G.E. Cushing - Candidate cave entrances on Mars. Journal of Cave and Karst Studies, v. 74, no. 1, p. 33-47. DOI: 10.4311/ 2010EX0167R

\title{
CANDIDATE CAVE ENTRANCES ON MARS
}

\author{
Glen E. Cushing \\ U.S. Geological Survey, Astrogeology Science Center, 2255 N. Gemini Dr., Flagstaff, AZ 86001, USA, gcushing@usgs.gov
}

\begin{abstract}
This paper presents newly discovered candidate cave entrances into Martian near-surface lava tubes, volcano-tectonic fracture systems, and pit craters and describes their characteristics and exploration possibilities. These candidates are all collapse features that occur either intermittently along laterally continuous trench-like depressions or in the floors of sheer-walled atypical pit craters. As viewed from orbit, locations of most candidates are visibly consistent with known terrestrial features such as tube-fed lava flows, volcano-tectonic fractures, and pit craters, each of which forms by mechanisms that can produce caves. Although we cannot determine subsurface extents of the Martian features discussed here, some may continue unimpeded for many kilometers if terrestrial examples are indeed analogous. The features presented here were identified in images acquired by the Mars Odyssey's Thermal Emission Imaging System visiblewavelength camera, and by the Mars Reconnaissance Orbiter's Context Camera. Select candidates have since been targeted by the High-Resolution Imaging Science Experiment. Martian caves are promising potential sites for future human habitation and astrobiology investigations; understanding their characteristics is critical for long-term mission planning and for developing the necessary exploration technologies.
\end{abstract}

\section{INTRODUCTION}

Since Oberbeck et al. (1969) first proposed that some lunar rilles might be collapsed lava tubes, the existence, characteristics, and potential utility of extraterrestrial cave systems have been extensively discussed, particularly for the Moon and Mars (e.g., Horz, 1985; Boston et al., 2003). Considering that basaltic volcanism is generally analogous between the Earth and Mars (e.g., Glaze et al., 2005), volcanic caves are believed to be fairly common on Mars (Cruikshank and Wood, 1972; Horz, 1985), but until recently, technical limitations, such as the spatial resolution, areal coverage, and viewing perspective of orbiting instruments have hindered their detection. Bleacher et al. (2007a, 2007b) identified numerous tube-fed lava-flow systems on the flanks of Olympus Mons and elsewhere in the Tharsis region of Mars and inferred some collapsed lava-tube sections to be skylights. However, they also suggested that the host lava tubes had completely collapsed and did not elaborate upon the possibility of intact cave systems. This paper presents new observations of candidate entrances into near-surface lava tubes and volcano-tectonic caves; morphological characteristics are examined and compared with terrestrial counterparts, and implications about formation mechanisms and exploration possibilities are discussed.

Caves are important to the future of Mars exploration because they are believed to provide shelter from a range of harsh surface conditions, maintaining near-pristine surfaces and relatively stable microclimates. Mars's thin atmosphere and negligible magnetic field do not effectively absorb, deflect, or moderate numerous hazards, including micrometeoroid impacts, dust storms, extreme temperature variations, and high fluxes of UV, alpha particles, and cosmic rays (e.g., Mazur et al., 1978; De Angeles et al., 2002; Boston et al., 2004; Cushing et al., 2007). Because organic materials cannot continuously withstand such hazards, caves may be among the few human-accessible locations that preserve evidence of whether microbial life ever existed on Mars. Caves may also become valuable resources for human explorers, who would otherwise have to transport their own shelters or construct them in place (e.g., Horz, 1985; Coombs and Hawke, 1992; Boston et al., 2003). Additionally, exploring and characterizing Mars's volcanic caves should enable us to constrain theories about lava-flow thermodynamics and hydrodynamics under Mars's gravity and atmospheric conditions. Volcanic and other types of caves may also protect mineral formations that either do not form or become buried or altered under surface conditions (Hill and Forti, 1997).

We surveyed all released images from Mars Odyssey's Thermal Emission Imaging System (THEMIS) and Mars Reconnaissance Orbiter's Context Camera (CTX) covering the flank flows and lava plains to the north of Arsia Mons $\left(235^{\circ}\right.$ to $243^{\circ} \mathrm{E},-8^{\circ}$ to $2^{\circ} \mathrm{N}$, Fig. 1$)$ because this is where the first cave-entrance candidates were identified (Cushing and Titus, 2010). Entrances into two distinctly different cave types exist in this region: near-surface lava-tube caves that form as singular, horizontal, curvilinear tunnels and volcano-tectonic caves that may extend downward into subsurface fractures. Although we cannot determine how far any of the Martian caves continue beneath the surface, it is likely that that many could be extensive if our comparisons with terrestrial examples are appropriate, because terrestrial volcanic caves can be tens of kilometers in length and hundreds of meters deep. Numerous smaller cave entrances appear to exist throughout the sample region, but these cases are not discussed here because they are too 


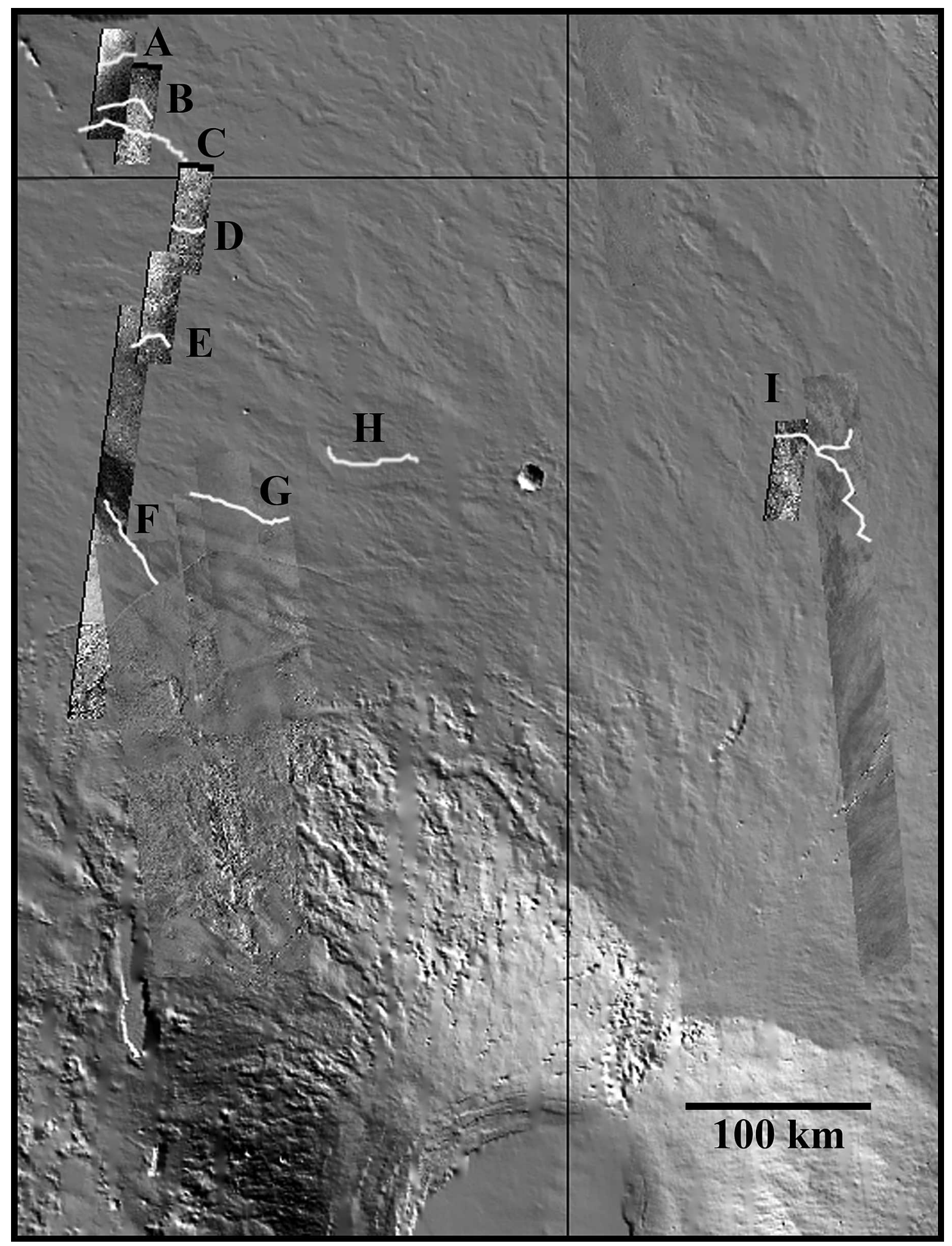

Figure 1. Context camera image showing the rift zone and lava plains north of Arsia Mons with the distribution of skylightbearing tube-fed lava flows (A-H) and the volcano-tectonic fracture system (I) listed in Table 1 (Image: MOLA 128 pixel-perdegree shaded relief from JMARS (Christensen et al., 2007)). 


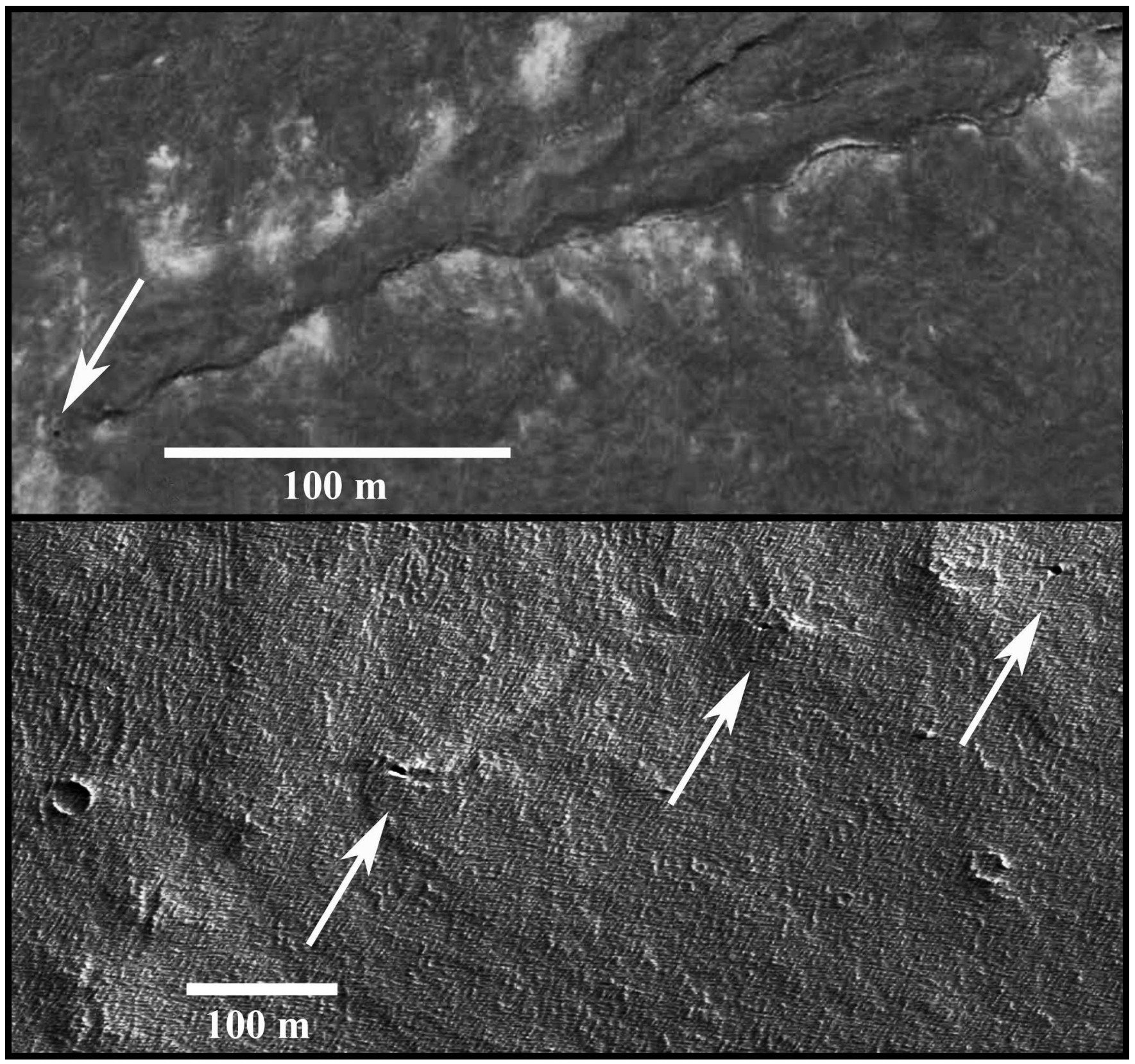

Figure 2. Comparison of inflated tube-fed lava flows (and their associated surface expressions). Top image shows an unnamed flow in Kïlauea volcano's eastern rift zone. Bottom image shows a proposed Martian tube-fed flow in the rift apron north of Arsia Mons (CTX: B02_010398_1751). Arrows indicate locations of candidate skylight entrances.

small and poorly resolved to be positively identified at this time.

\section{SOURCE DATA}

THEMIS consists of two cameras that record visible and thermal-infrared wavelengths. The visible-wavelength camera observes the Martian surface at 18 or $36 \mathrm{~m} /$ pixel in five discrete bands that cover the visible to near-IR spectrum between $\sim 0.4$ and $\sim 0.9 \mu \mathrm{m}$ (Christensen et al., 2004). In this study, we use only band-3 data ( 0.654 \pm
$0.053 \mu \mathrm{m}$ ) because it is acquired in most observations and provides the highest signal-to-noise ratio. At $\sim 100 \mathrm{~m} /$ pixel, THEMIS thermal-infrared data are too coarse to detect the features presented here. CTX detects a broad band of visible wavelengths $(\sim 0.5-0.8 \mu \mathrm{m})$ at $\sim 6 \mathrm{~m} /$ pixel (Malin et al., 2007), allowing more precise measurements to be taken and enabling features that are small or ambiguous in THEMIS data to be more clearly identified. As of June 2010, CTX coverage did not include much of the region north of Arsia Mons, where THEMIS identified many of the tube-fed flows and fractures discussed here. THEMIS 
and CTX datasets are appropriate to conduct surveytype searches for cave entrances because each observation covers hundreds of square kilometes, and they cumulatively cover the majority of Mars's total surface area. The Mars Reconnaissance Orbiter's High-Resolution Imaging Science Experiment (HiRISE) is a visible-wavelength camera that observes at ultra-fine resolution down to $\sim 0.25 \mathrm{~m} /$ pixel, giving pixels about 1/5000 the size of a THEMIS pixel (McEwen et al., 2007) that allows precise measurements to be taken and fine-scale morphologies and surface textures to be evaluated. Because the MRO performs routine roll maneuvers about its direction of motion, HiRISE and CTX can observe objects from an off-nadir perspective. This is useful in determining whether a vertical wall or an overhanging rim is present around the skylights. Because HiRISE will cover only a small portion of Mars during its lifetime $(\sim 1 \%$ during its initial two-year primary science phase (McEwen et al., 2007), its targets are carefully chosen and limited to specific and scientifically relevant locations, usually based on THEMIS or CTX observations.

\section{Lava-Tube Caves}

Lava tubes are insulated subsurface conduits that allow, or once allowed, flowing lava to maintain high temperatures, and thus low viscosity, as it travels from a source vent to distant flow margins (e.g., Wentworth and MacDonald, 1953; Greeley, 1971a, 1971b, 1972; Keszthelyi, 1995; Sakimoto et al., 1997). These are common structures in basaltic pāhoehoe-type lava flows and facilitate the spread of evolved mafic lava flows by enabling large volumes to be transported over long distances (Wentworth and MacDonald, 1953; Keszthelyi and Self, 1998). If the flow of lava through an established tube becomes either diminished or diverted, then the tube may drain and leave an empty, intact, and structurally competent tunnel. Surface entrances (skylights) may exist where portions of lavatube ceilings either never completely formed or have collapsed. Occurring frequently in terrestrial basaltic volcanism, lava tubes are expected to be common in Mars's volcanic regions as well (e.g., Horz, 1985; Keszthelyi, 1995; Sakimoto et al., 1997).

On Mars, numerous sinuous and linear depressions in volcanic regions appear similar to orbital views of inflated tube-fed lava flows on Earth (Fig. 2). These depressions are channel-like in appearance and follow single, sinuous paths that extend along the crests of 10 to $20 \mathrm{~m}$ topographic rises with laterally spreading flanks that often form chains of either tumuli or vent structures. This morphology is a telltale indicator of a tube-fed system emplaced by inflation, which can be a dominant pāhoehoe mechanism across low slopes (Kauahikaua, et al., 2003). Inflated tubefed lava flows often develop downward-propagating cracks (running along the direction of flow, Fig. 2) that form when the cooled and hardened lava-tube ceiling is raised due to internal pressure from subsequent magma-injection episodes (e.g., Self et al., 1998; Kauahikaua, et al., 2003, Glaze et al., 2005). However, some of the tubes presented here have sections where the axial trench does not sit atop a topographic rise, but instead cuts downward into the surface and shows no evidence of inflation (e.g., Fig. 3). These apparently non-inflated lava-tube sections may have initially began as channelized flows that eventually crusted over to form insulated conduits (e.g., Wentworth and MacDonald, 1953; Greeley, 1971a, 1971b). Lava tubes that neither begin as open channels nor become inflated by internal pressures may exhibit little or no visible surface expression, and often can only be identified by the presence of skylight entrances (e.g., Daga et al., 1988; Greeley, 1972; Calvari and Pinkerton, 1999; Miyamoto et al., 2005). Although the surface grooves described here are sometimes thought to be completely collapsed lava tubes, it is important to emphasize that these features are more likely to be either dilational fractures from inflation or the upper surfaces of former channelized flows. They do not necessarily indicate the diameter of an underlying evacuated tube, that internal collapse has occurred, or even that the tube system ever drained to form an empty tunnel. Here we suggest that the presence of skylight entrances into these trenches indicates that draining did indeed occur at those locations and that lava tubes are likely to remain at least partially intact beneath the surface (Figs. 3 and 4 top).

Keszthelyi (1995) and Sakimoto et al. (1997) modeled the thermodynamics of lava-tube formation to determine how tube lengths and diameters on various planetary bodies would be related to properties such as lava viscosity, effusion rates, regional slopes, gravity, and atmosphere. The tube-fed flows on Mars observed to contain skylights show surface expressions up to $71 \mathrm{~km}$ long, which is considerably shorter than the maximum modeled lengths of up to $1000 \mathrm{~km}$, so these tubes, whose source vents are not seen in the vicinity, could extend much farther upslope.

The proposed lava-tube skylights discussed here occur within several tube-fed flows (Table 1). These entrances are less than $60 \mathrm{~m}$ across, at least 10 to $30 \mathrm{~m}$ deep, and do not extend laterally beyond the channels or trenches that contain them. In some cases where inflation effects are not apparent, the skylights occur in relatively flat surfaces where they have caused wind-streak patterns to form (Fig. 4, top) and appear to be at least partially filled with in-blown dust.

To be classified as a candidate lava-tube skylight in this paper, a feature must have at least one pixel that is darker than the shadows cast by nearby surface features such as crater rims, exist within a sinuous trench that runs axially along a tube-fed lava flow, be substantially deeper than its host trench, and not have characteristics normally associated with impact craters such as raised rims or ejecta patterns. Bleacher et al. (2007a) observed lava-tube skylights in THEMIS image V11326014, but these are unlikely caveentrance candidates because they are not as dark as nearby shadowed regions and are no deeper than their host trench. 


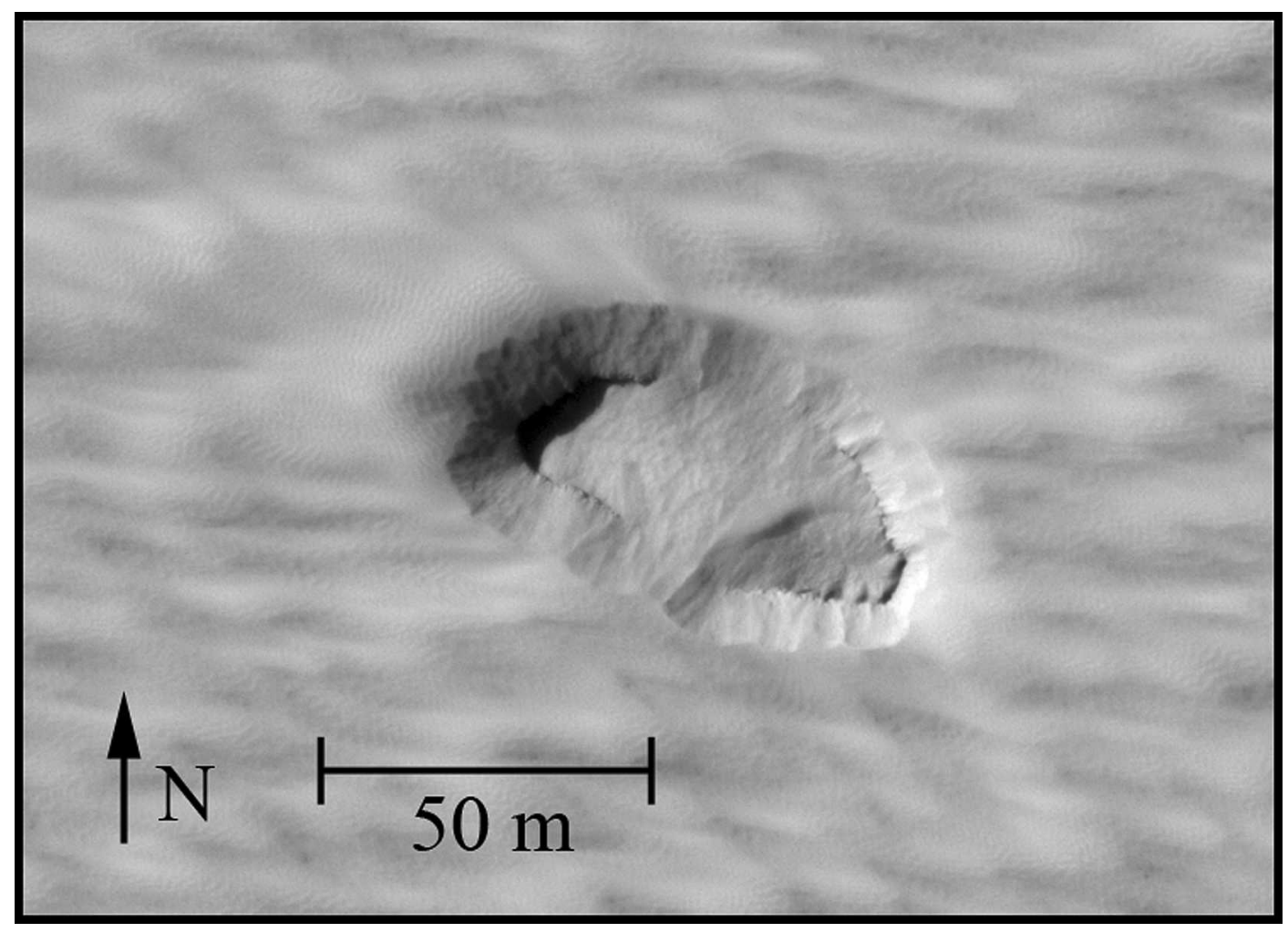

Figure 3. HiRISE ESP_016767_1785 (along flow F in Figure 1). Collapsed lava-tube section that's been partially filled by windblown dust. Cave entrance might be accessible by a vehicle.

\section{Volcano-Tectonic Caves}

The other type of linear surface depression observed to contain cave entrances is located at the distal edge of the Arsia Mons northwest-flank vent flows, approximately midway between Arsia Mons and Pavonis Mons and $\sim 200 \mathrm{~km}$ east of the aforementioned tube-fed flows (I in Fig. 1). This structure shows evidence of both volcanic and tectonic mechanisms and is clearly different from the trenches associated with tube-fed lava flows in several ways. It is substantially wider than the fractures found along the crests of tube-fed flows and is composed of 10 to $20 \mathrm{~km}$ linear or curvilinear, rather than sinuous, segments that cut across numerous lava flows and conjoin at sharp angles, usually between 95 and $110^{\circ}$ (Figs. 5, 6, and 7). Collectively, the connected fractures extend more than $100 \mathrm{~km}$. This structure does not contain tumuli, outflow vents, or topographic high points, but instead has grabenlike depressions with broad, flat floors and no apparent vertical offset between opposing walls. A regional dust mantle up to several meters thick masks any parallel normal faults that could indicate whether a graben-type collapse occurred. The lengths, segmentation, location, and orientation of these fractures, which are between Arsia Mons and Pavonis Mons and aligned with the Tharsisridge volcanic system, suggest they may have formed through deep tectonic processes associated with the Tharsis regional uplift (Banerdt et al., 1992; Phillips et al., 1990). Dilational tectonic fractures of this magnitude could extend downward as far as $5 \mathrm{~km}$ beneath the surface (Ferrill et al., 2003), where they were likely intruded and widened by magma, thus inducing formation of the observed grabens and cave entrances. As with the lava-tube skylights, the volcano-tectonic cave entrances are no wider than the fractures in which they formed. However, unlike lava-tube caves, which tend to be sinuous, remain relatively near the upper surface, and follow regional slopes, volcano-tectonic caves could extend deep into their host fractures and branch into complicated subsurface networks (Coons, 2010).

Visible evidence that low-viscosity materials flowed out of this fracture network can be seen in the form of occasional rim levees and a substantial outflow feature with distinctly fluvial-like streamlined braids where a large volume of fluid laterally breached the fracture walls in the down-slope direction (Fig. 7). If this fluid was lava, then its viscosity must have been exceptionally low to form such a fluvial pattern. Jaeger et al. (2010) rigorously examined a similar example in Athabasca Vallis, where fluvial-like features were carved by mafic or ultra-mafic flood basalts with viscosities possibly as low as $10 \mathrm{~Pa} \cdot \mathrm{s}$. On the other hand, the streamlined islands in this outflow feature may have formed from an outbreak of liquid water, as the Tharsis region contains multiple examples of fluvial-type 


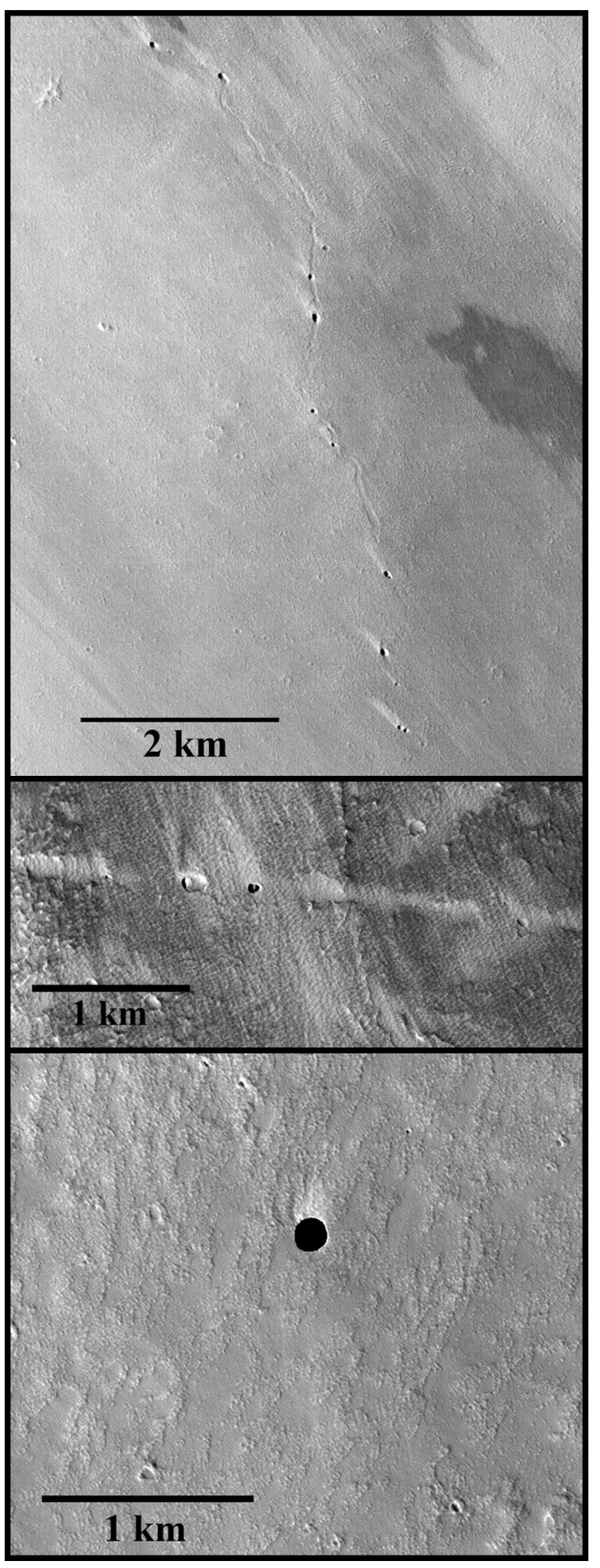

Figure 4. Three different cave entrance candidate types on Mars. Top image shows a lava-tube rille with multiple skylight entrances (CTX: P17_007774_1757); the center image is a volcano-tectonic fracture with a skylight entrance (HiRISE: ESP_014380_1775, detail in Figure 8); and the bottom image is an atypical pit crater with a diameter of channels (Mouginis-Mark, 1990; Mouginis-Mark and Christensen, 2005), and water-ice clouds form above Arsia Mons nearly every day of the year (Noe Dobrea and Bell, 2005; Benson et al., 2006).

An appropriate terrestrial comparison to this Martian volcano-tectonic fracture system may be the Great Crack (Fig. 6, top) in Kîlauea volcano's southwest rift zone. The Great Crack is a linear series of fractures, grabens, and pitcrater chains that extend from Kîlauea's caldera to the ocean. This structure formed when upwelling magma intruded into a dike-induced fracture during the 1823 Kîlauea flow event, thus widening the fracture and forming a dike that transported material more than $35 \mathrm{~km}$ from the source. Normal faulting and stoping above this dike caused a series pit craters and grabens to form (Okubo and Martel, 1998), along with a number of deep and extensive caves, some of which have been explored to depths exceeding $180 \mathrm{~m}$ (Coons, 2010). Although the Great Crack is likely a nontectonic feature caused by forced magmatic intrusion, while the Martian cracks were likely widened when magma flowed into pre-existing tectonic fractures, these mechanisms both involve interactions between fractures and magma and may have created similar opportunities for magma to drain and produce comparable surface expressions such as pits and fracture caves at the sub-kilometer scale.

Figure 8 shows the only currently released HiRISE observation of a volcano-tectonic fracture skylight where an overhanging, dust-mantled rim and an interior mound that is either dust or dust-covered are clearly resolved. Specifics of this skylight are discussed in the measurements section.

\section{Atypical Pit Craters}

A different type of cave entrance is described by Cushing et al. (2007), who discuss a number of steepwalled depressions that appear to be special cases of common pit craters (Fig. 4, bottom). Atypical Pit Craters (APC) are not associated with surface grooves and are nearly always circular, with diameters of $\sim 80$ to $300 \mathrm{~m}$. HiRISE shows that some APCs are deep, sheer-walled cylindrical structures with no apparent subsurface extent, while others extend laterally beneath overhanging rims for unknown distances (Cushing et al., 2008). Figure 9 shows an APC where a candidate cave entrance can be seen in its floor; the image has been contrast-enhanced to display the instrument's low-radiance limit. Figure 10 shows what appears to be a common pit crater with a central skylight entrance into which surface materials likely continue to drain. This example is possibly unique on Mars, and it

$\sim 165 \mathrm{~m}$, a depth $>245 \mathrm{~m}$, and an overhanging rim of unknown extent (HiRISE: PSP_003647_1745). 


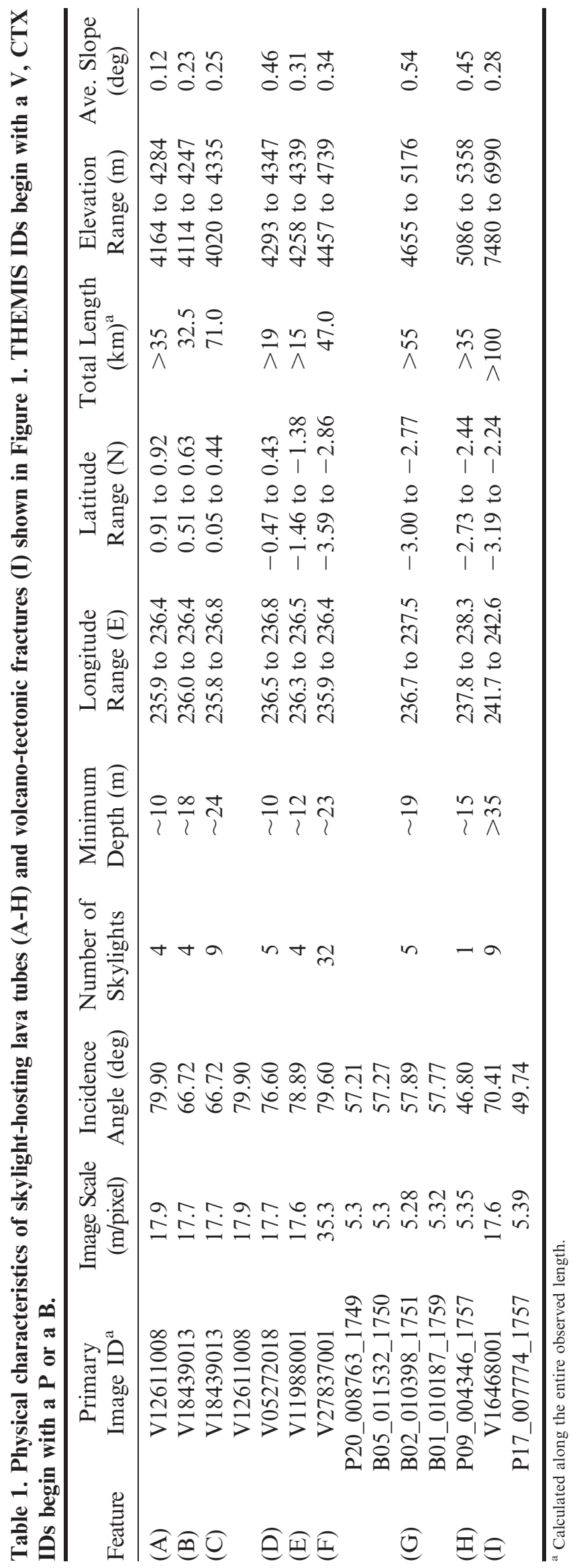

could represent an intermediate, possibly ongoing formation stage of either an APC, if ceiling collapse progresses outward, or a common pit crater, if draining surface materials eventually fill the skylight. Haruyama et al. (2009) recently discovered a lunar feature in an ancient lava channel that looks identical to Martian APCs and suggest it may be a skylight entrance into a deep lava tube. Table 2 shows a comparison of the three different cave-entrance types.

\section{Measurements}

The Mars Orbiter Laser Altimeter on the Mars Global Surveyor measured surface elevations across Mars (Zuber et al., 1992) with a vertical resolution of $\sim 1 \mathrm{~m}$, and we used a dataset binned to a spatial resolution (equatorial) of approximately 256 pixels per degree, or $\sim 230 \mathrm{~m}$. We used the Java Mission-planning and Analysis for Remote Sensing (JMARS) tool (Christensen et al., 2007) to register MOLA with visible observations and determine the elevation profile for each feature containing at least one candidate skylight entrance. All the observed tube-fed flows run continuously down-slope at shallow angles averaging $\sim 0.5^{\circ}$ or less, and the volcano-tectonic fractures average $\sim 0.3^{\circ}$ down-slope with occasional minor rises (Fig. 11; Table 1).

In THEMIS observations, most of the skylight entrances are on the scale of only a few pixels or less, so accurate dimensions with reasonable error estimates cannot be determined from the spatial extent of pixels alone. Horizontal dimensions of the skylights were calculated by fitting an ellipse to the dark pixels corresponding to each feature, assuming that pixels outside of the ellipse match the median pixel value of the scene while those inside of the ellipse match either the minimum pixel in the scene or zero DN (Digital Number value). The scene was reconstructed assuming subpixel mixing between the inside and outside of the ellipse, and the estimated DN for each pixel was weighted by the area of the ellipse contained within that pixel. The location, major and minor axes, and rotation of the major axis were varied until the root-mean-square difference between the actual scene (at the median-value threshold) and the reconstructed scene was minimized (Fig. 12).

To estimate the depth (d) of a floor beneath a skylight entrance in THEMIS images, we assumed a nadir viewing perspective and divided the length $\left(D_{\mathrm{s}}\right)$ of the interior shadow cast by the rim in the direction of illumination by the tangent of the observed solar incidence angle $(i)$. In most cases, the lava-tube floors are sufficiently deep, $i$ is sufficiently large, and the full diameter along the line of illumination $\left(D_{\mathrm{i}}\right)$ is sufficiently small that the shadowed/ sunlit boundary cannot be seen (so $D_{\mathrm{s}}=D_{\mathrm{i}}$ ), and only a minimum value for depth can be obtained. Assuming that lava-tube floors maintain essentially constant depths beneath the surface, the largest skylights indicate that interior floors run at least 15 to $30 \mathrm{~m}$ below the surface. 


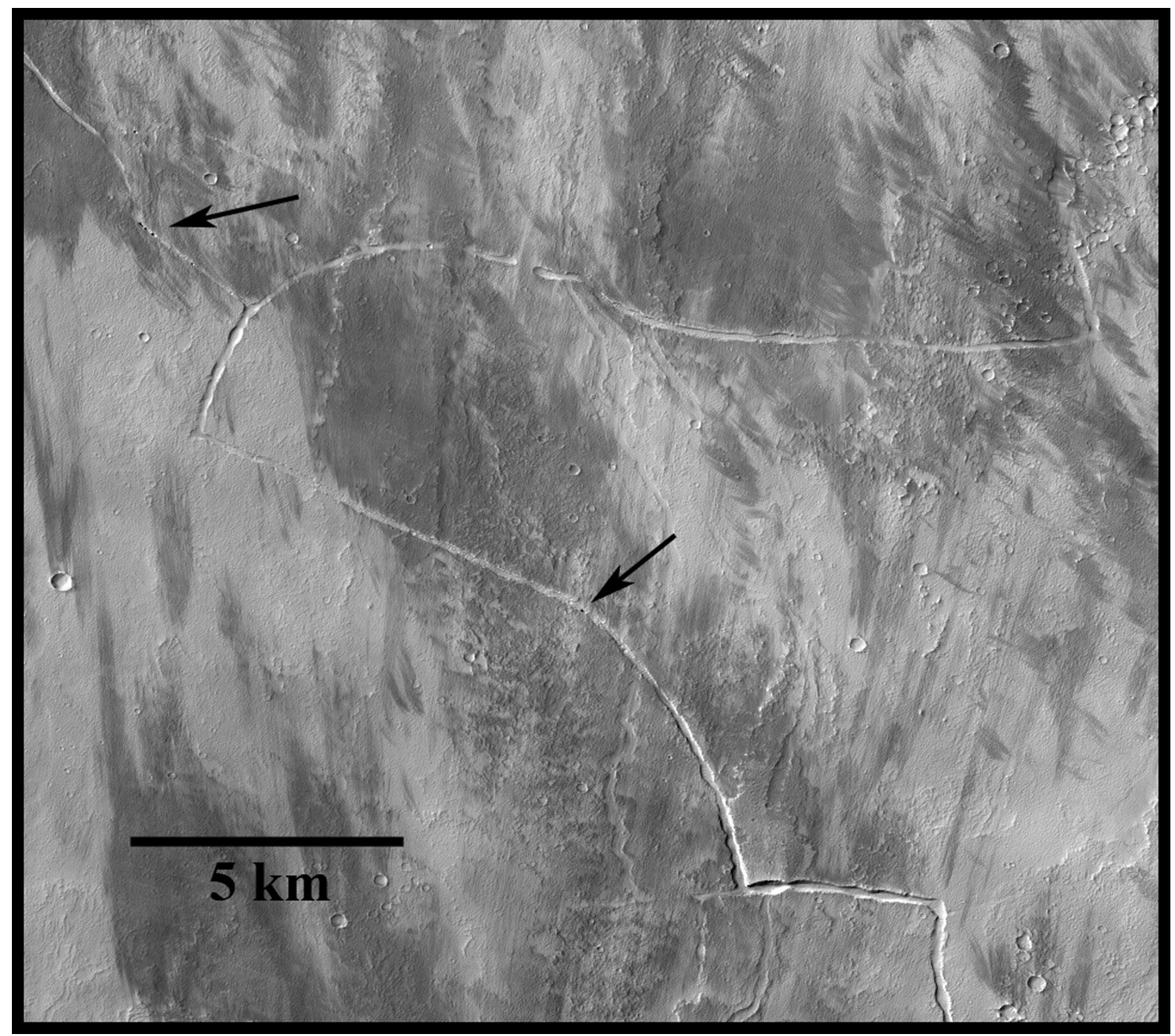

Figure 5. A small portion of the proposed volcano-tectonic fracture network, shown here to illustrate its fracturelike appearance from orbit (CTX: P17_007774_1757). The entire network spans $>100 \mathrm{~km}$. Figure 6 shows part of this feature compared with a terrestrial analog, Figure 7 shows evidence that low-viscosity fluid flowed through the network, and Figure 8 details one of its skylight entrances. North is upward; arrows indicate candidate skylight entrances.

HiRISE has observed one fracture-cave skylight thus far, looking slightly off nadir at an angle of $6.8^{\circ}$ (see Fig. 8). This image shows a large central mound, not apparent in THEMIS observations, that appears to be composed of either dust or dust-covered rubble. The major and minor axes of this feature are $\sim 68 \mathrm{~m}$ and $\sim 48 \mathrm{~m}$, respectively, which are within the error bounds of our ellipse fitted to the THEMIS data. Based on the solar incidence of $35^{\circ}$, we can determine that the depth at the edge of the shadow is approximately $37 \mathrm{~m}$. Accordingly, if slopes of the central mound are at the angle of repose $(\sim 30$ to $40^{\circ}$ ), then the peak of the mound is approximately 19 to $25 \mathrm{~m}$ beneath the surface level, and the non-illuminated area directly below the western rim is at least 49 to $55 \mathrm{~m}$ deep if the mound slopes consistently downward to that point. The entrance ledge appears to completely encircle the pit and slopes inward from the surface so that the dust/ rock interface can be discerned. Assuming these materials lie at the angle of repose, the upper overhanging ledge is approximately $5.5 \mathrm{~m}$ to $8.5 \mathrm{~m}$ thick, with the uppermost 3 or $4 \mathrm{~m}$ being composed of dust mantling $2.5 \mathrm{~m}$ to $4.5 \mathrm{~m}$ of bedrock. 


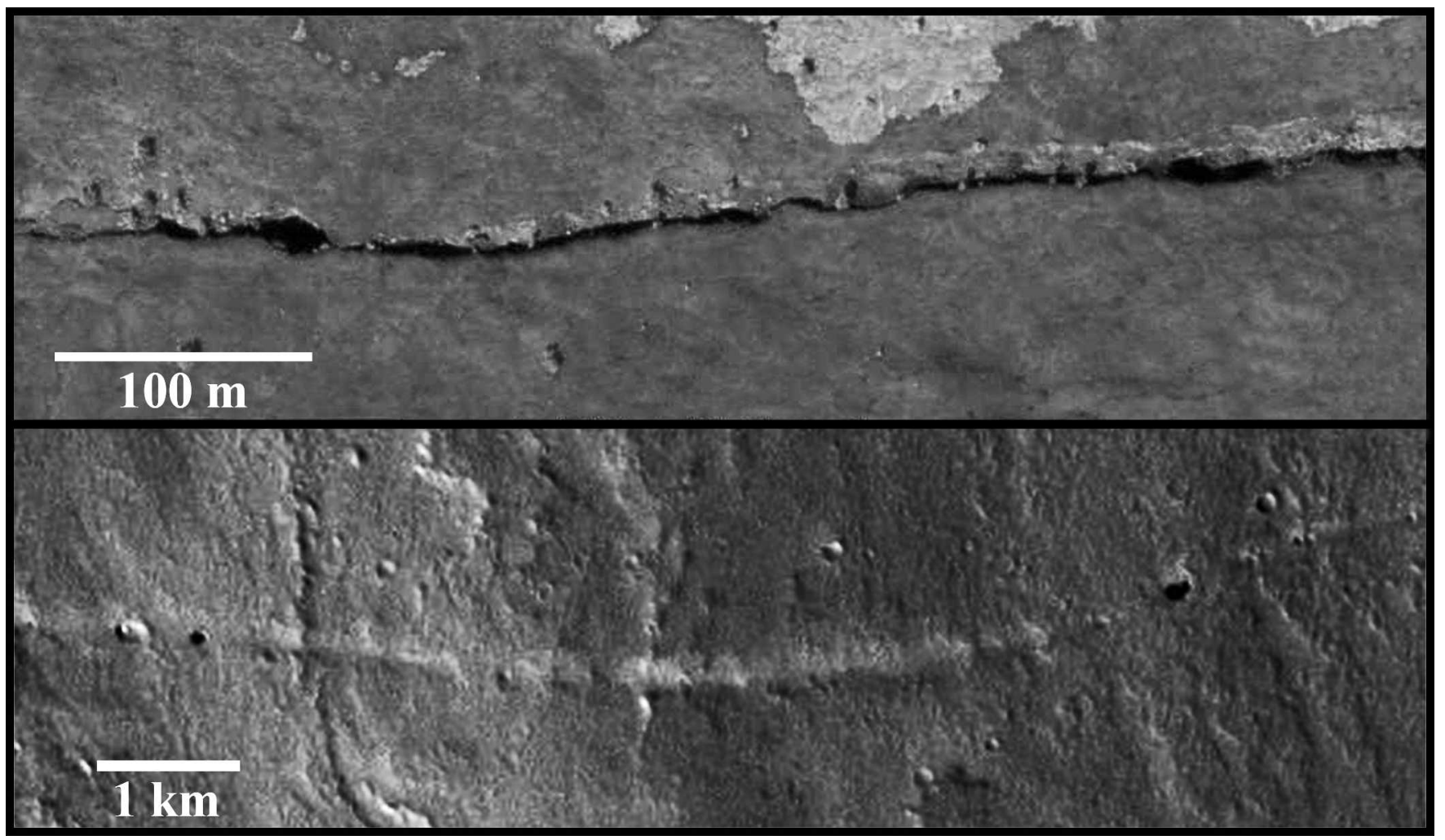

Figure 6. Volcano-tectonic fracture systems on Earth and Mars. Top image shows a portion of the Great Crack in Kïlauea volcano's southwest rift zone. Bottom image shows a portion of a proposed Martian volcano-tectonic fracture network located north of Arsia Mons (THEMIS V16468001).

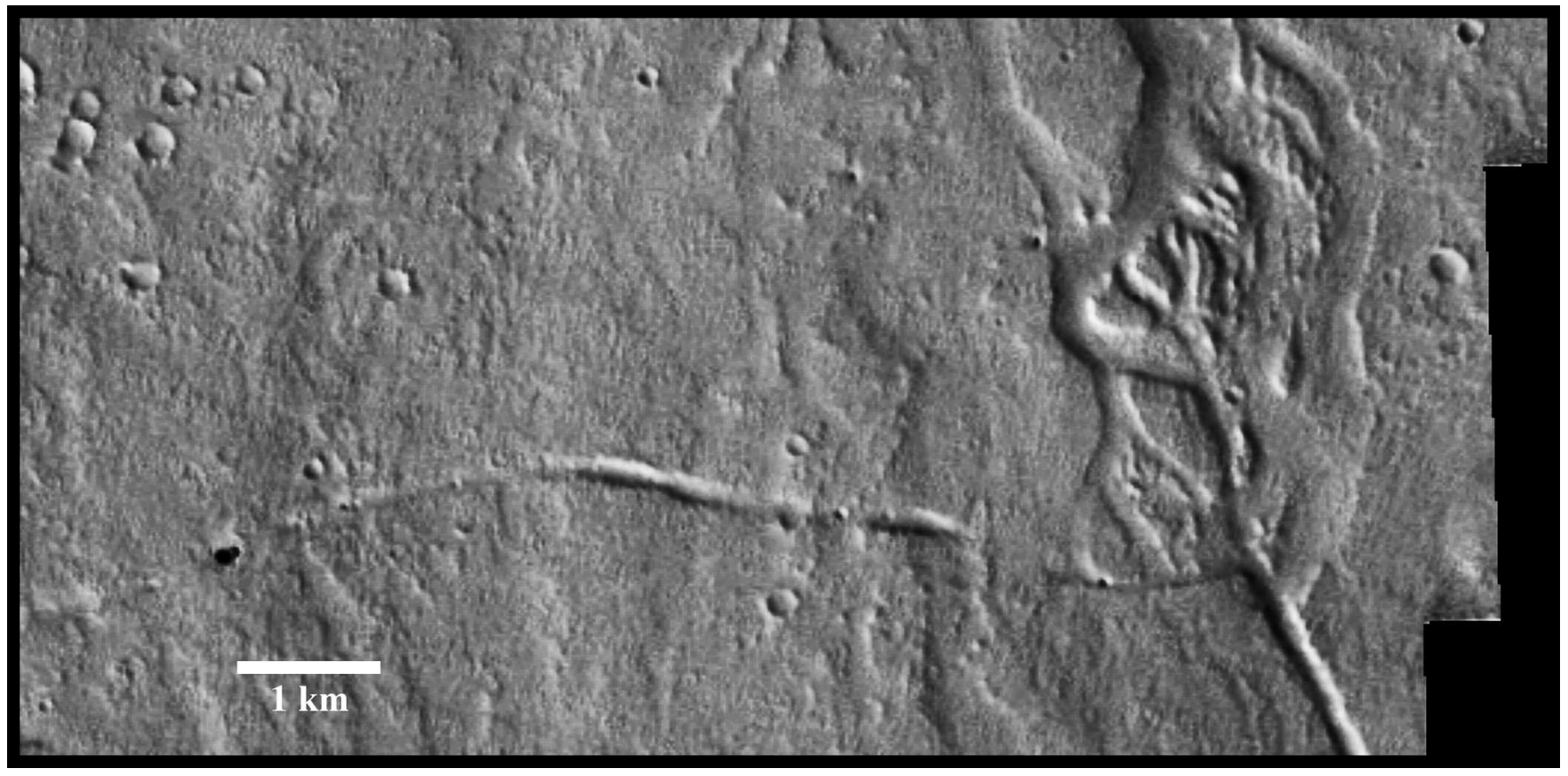

Figure 7. Evidence that low-viscosity fluid flowed through pre-existing tectonic fractures. Detail of feature I in Figure 1; at the right, fluid laterally breached its containment and flowed across the surface, creating a fluvial-like pattern (THEMIS V16468001). 


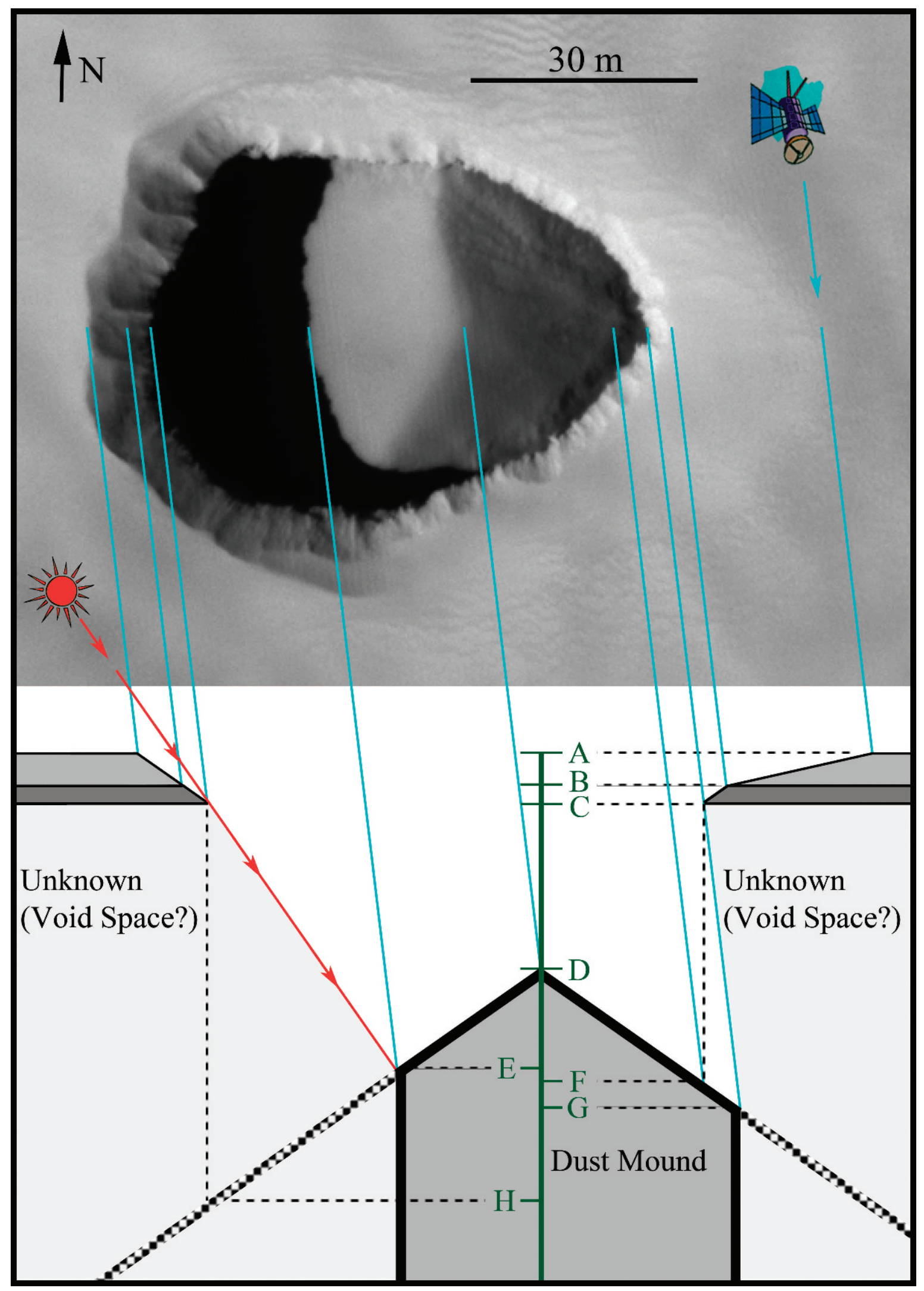

Figure 8. Detail of skylight in HiRISE: ESP_014380_1775 (also shown in the bottom of Fig. 4). Solar incidence angle $=35^{\circ}$, viewing angle $=6.8^{\circ}$ from vertical. Diameter $=\sim 68 \mathrm{~m}$ (measured from interior rim edges). North is upward. Approximate depths: $\mathrm{A}-\mathrm{B} \approx 4 \mathrm{~m}$ (dust layer); $\mathrm{B}-\mathrm{C} \approx 3 \mathrm{~m}$ (bedrock overhang); $\mathrm{A}-\mathrm{D} \approx 22 \mathrm{~m}$ (depth to top of mound); $\mathrm{A}-\mathrm{E} \approx 37 \mathrm{~m}$ (depth to 


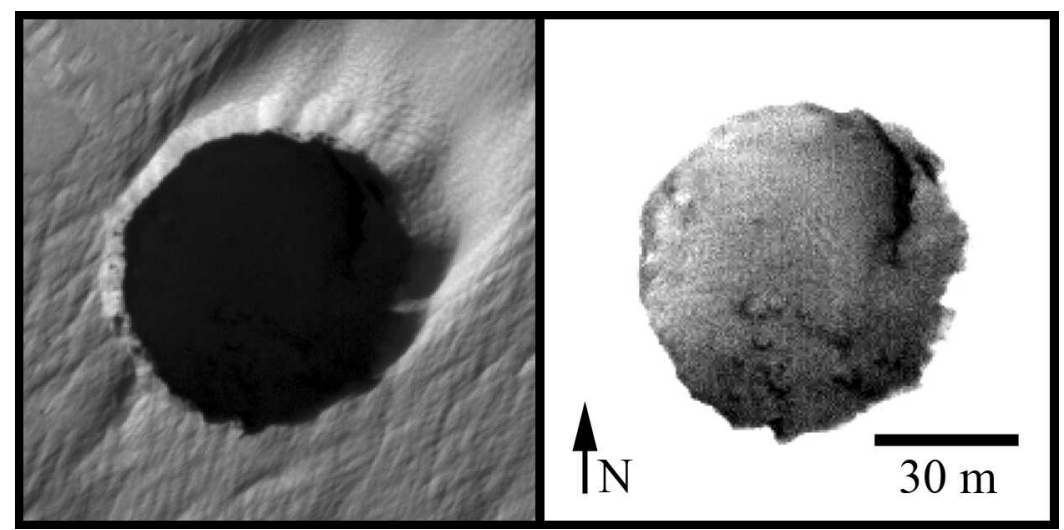

Figure 9. HiRISE image ESP_016622_1660. Right panel shows same image as left, but with contrast stretched to display the instrument's low-end radiance threshold to reveal a candidate entrance to a cave that may extend from the upper right. This pit is $\sim 65 \mathrm{~m}$ across and $>45 \mathrm{~m}$ deep.

\section{Summary AND Discussion}

The cave entrances and their respective host structures appear to be younger than their surroundings, not covered or crosscut by other flows or fractures, but their absolute ages cannot be determined with certainty because tube-fed flows can be much younger than the surfaces they cross. However, the entire sample region is late Amazonian in age $(<500 \mathrm{Ma})$ based on crater size-frequency distributions (Plescia and Saunders, 1979; Neukum and Hiller, 1981; Werner, 2005), with some areas possibly as young as $50 \mathrm{Ma}$ (Werner, 2005).

\section{EXPLORATION}

Several technologies must be advanced before robotic explorers can visit Martian caves. Precision landing techniques must be developed to place spacecraft at such small targets, and means of entering and exploring cave environments while maintaining contact with the surface must also be developed (e.g., Boston et al., 2003, 2004: Léveille and Datta, 2010). Furthermore, internationally agreed planetary protection policies forbid any visits to candidate astrobiology sites until microbial contamination issues can be addressed (COSPAR, 2008). Regardless of the challenges ahead, our identification of viable cave targets is an important step toward developing an entire new category of planetary exploration technologies.

\section{Human Habitat Potential}

From terrestrial examples, lava-tube caves, especially those with long, unbroken extents and flat, relatively smooth floors, are particularly suitable to host human habitats on Mars. Additionally, lava tubes usually have sufficient lateral extent to isolate their interiors from nearentrance surface hazards. Lava-tube caves, by their nature, can protect inhabitants from all of the hazards that humans would encounter on the surface. Dust storms and micrometeoroids cannot reach cave interiors, temperature variations are minimized in cave environments (e.g., Boston et al., 2001; Wynne et al., 2008), and roof thicknesses of only 1 to $2 \mathrm{~m}$ can effectively shield against all types of incoming radiation (NCRP, 2001; De Angeles, 2002).

For either small exploration teams or communities of future colonists, lava tubes may be the safest and most economical option to protect humans on Mars. Transporting or constructing shelters that adequately protect human visitors on the surface of Mars may be unrealistic in terms of resource consumption, especially since features such as lava tubes that can provide much of the necessary protection may already be present.

\section{WATER ICE}

Besides providing suitable shelter, caves are potential reservoirs of stable or metastable water-ice deposits, which could be an invaluable resource. Being highly insulated environments, caves that extend at downward angles into the surface will trap and hold cold air to form isolated microclimates (e.g., Balch, 1900; Halliday, 1954, Ingham et al., 2008). If conditions are favorable, then cave ice could either condense and accumulate at rates that exceed sublimation or could remain trapped there after forming in more favorable times. Williams et al. (2010) rigorously modeled cave-ice deposition and stability for various

$\leftarrow$

shadow edge); $A-F \approx 38 \mathrm{~m}$ (depth directly below east rim); $\mathrm{A}-\mathrm{G} \approx \mathbf{4 0} \mathrm{m}$ (maximum visible depth); $\mathrm{A}-\mathrm{H} \approx 52 \mathrm{~m}$ (depth directly below west rim assuming the mound slopes continuously downward at the angle of repose.) Values for this figure were calculated assuming an angle of repose of $35^{\circ}$. 


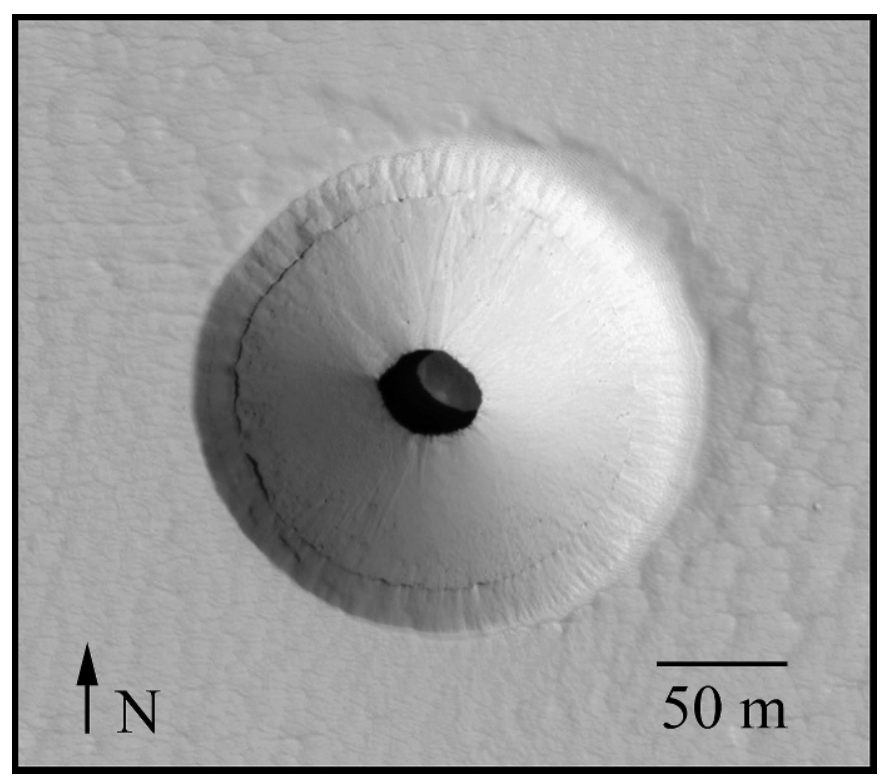

Figure 10. HiRISE image ESP_023531_1840. The main pit is $\sim 195 \mathrm{~m}$ across and the central skylight is $\sim 40 \mathrm{~m}$ across at the widest point. Assuming the inner slopes rest at the angle of repose $\left(\sim 35^{\circ}\right)$, the skylight is approximately $50 \mathrm{~m}$ below the surface, and shadow measurements indicate a further drop of $\sim 25 \mathrm{~m}$ to the center of the floor. This feature may represent an intermediate formation stage for either atypical pit craters or common volcanic pit craters.

locations on Mars, concluding that subsurface water-ice can exist for long periods across much of the planet and that conditions are particularly favorable in the Tharsis region, in which many caves are located. These caves are in advantageous locations for ice to accumulate because water-ice clouds are observed to form nearly every day of the Martian year above and around Arsia Mons (Benson et al., 2003, 2006; Maltagliati et al., 2008). Cold trapping and ice condensation is well documented for numerous terrestrial caves (e.g., Balch 1900; Halliday, 1954; Ingham et al., 2008) and occurs even in arid desert environments.

There is also strong evidence that the western flank of Arsia Mon, which is adjacent to our study area, becomes glaciated during periods of high obliquity (Head and Marchant, 2003; Shean et al., 2007), and thermal-diffusion models indicate that a subsurface ice table should still persist underneath a desiccated layer of dust (Helbert et al., 2006). If ice entered the nearby caves during these periods, then some of it may still be preserved by a combination of insulation by in-blown surface dust, cold trapping, and the absence of solar radiation. If such ancient deposits of water-ice indeed still exist, they may preserve atmospheric samples from the past that contain valuable information about Mars's climate history (e.g., Dansgaard et al., 1993).

\section{Astrobiology}

Nearly all known caves on Earth host communities of microorganisms and caves are among the most likely places to find evidence of past or present microbial life on Mars. However, the examples presented here are unlikely prospects for astrobiology due to their location. The Tharsis Montes volcanic region is among the youngest surfaces on Mars and had not yet formed when conditions were conducive for the development of life as we understand it. Accordingly, older caves, perhaps formed by aqueous processes, where life might have retreated underground as the Martian surface became increasingly inhospitable are more likely to contain evidence of past or extant life (Grin et al., 1998; Cabrol et al., 2009). Nonetheless, all manner of extraterrestrial cave discoveries are valuable to the future of astrobiology because they encourage study and preparation for future cave-specific missions.

\section{FUTURE WORK}

Continuing HiRISE observations of cave entrances will provide important details such as accurate measurements and fine-scale morphologies that cannot be resolved by THEMIS or CTX. Besides allowing for highly accurate dimensional measurements, HiRISE may also allow us to constrain values for local dust-mantle thicknesses, nearentrance roof thicknesses (in off-nadir observations), and floor characteristics. Especially in lava-tube caves, characteristics of floor materials that lie directly beneath skylight entrances can indicate when the skylight formed in relation to the flow. For example, rubble piles would indicate that roof collapse occurred subsequent to flow activity, while smooth floors could suggest that the collapsed materials fell into viscous lava and either sank or were transported away. Smooth-floor lava tubes will be important targets for future cave-exploration because they are likely safer and simpler to enter, navigate, and possibly even inhabit, compared with rough-floored lava tubes, volcano-tectonic caves, or atypical pit craters.

The structures discussed here exist within a limited area, and other examples are likely to exist in other volcanic

Table 2. Identification criteria for different cave-entrance types around Arsia Mons.

\begin{tabular}{lccccc}
\hline Cave-Entrance Type & Volcanic? & Tectonic? & Associated Rille? & Visible in IR? & Circular? \\
\hline Lava-tube Skylight & $\mathrm{Y}$ & $\mathrm{N}$ & $\mathrm{Y}$ & $\mathrm{N}$ & Occasionally \\
Fracture Skylight & $\mathrm{Y}$ & $\mathrm{Y}$ & $\mathrm{Y}$ & $\mathrm{N}$ & Occasionally \\
Atypical Pit Craters & $?$ & $?$ & $\mathrm{~N}$ & $\mathrm{Y}$ & $\mathrm{Y}$ \\
\hline
\end{tabular}




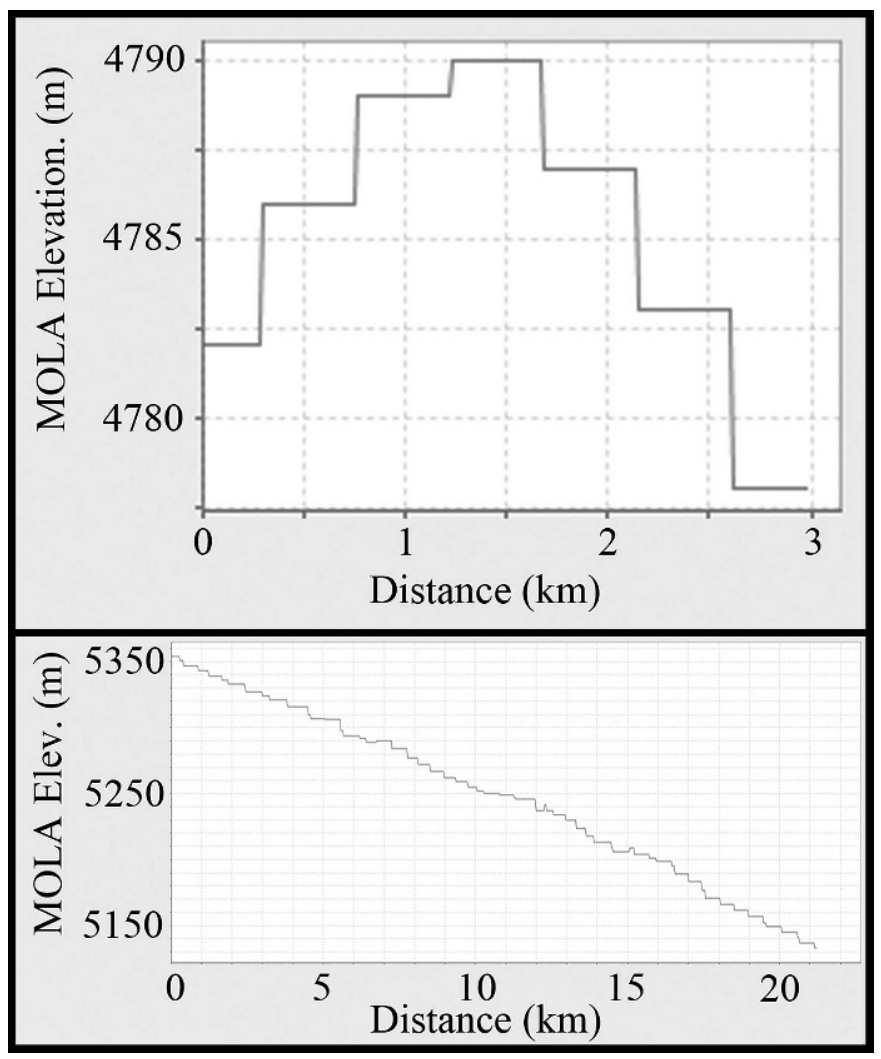

Figure 11. Lava-tube elevation profiles from 128 pixel per degree gridded Mars Orbiter Laser Altimeter data. Top profile runs across an inflated tube-fed flow; rilles are not resolved at this resolution. Lower profile runs along the length of a tube-fed flow, showing its continuous downslope character.

regions across Mars. THEMIS and CTX data will be used to conduct a planet-wide survey, concentrating mostly on volcanic regions where comparable features are most likely to occur. Additional cave entrance candidates will be suggested as HiRISE targets. Caves detected in older regions, which may be more suitable astrobiology targets, will be compared with those presented here to reveal details about how these structures evolve over time due to collapse, erosion, or burial.

Future thermal-infrared observations can provide important additional information about these caves that is not available at visible wavelengths. Diurnal and annual temperature variations inside a cave can be influenced by its depth and overall subsurface extent (e.g., Ingham et al., 2008; Wynne et al., 2008), and cave internal surface temperatures tend to represent the mean annual temperature at the surface (Cropley, 1965; Pflitsch and Piasecki, 2003; Wynne et al., 2008) unless complex heat-transport mechanisms, such as seasonal ventilation due to multiple entrances, exist. For example, deep caves that trap cold air should have mean internal surface temperatures that are lower than average, while short, shallow caves can be influenced by solar insolation at their entrances and have

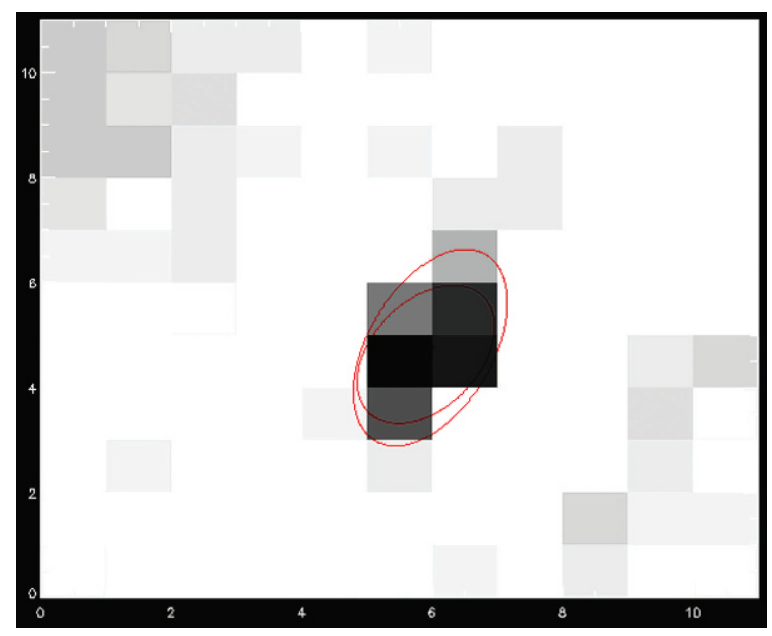

Figure 12. Best-fit ellipses for size for two different haze values, with surface pixels set to the median digital value of the scene.

mean temperatures that are higher than average. The caves presented here are too small to be detected in $100 \mathrm{~m} / \mathrm{pixel}$ THEMIS IR data, so before their temperature variations can be analyzed, the next generation of thermal-infrared camera, which should have a resolution of $10 \mathrm{~m} /$ pixel or better, must be placed in orbit.

Because volcanic regions are extensive across Mars, the discovery of cave entrances within them has long been anticipated. At least three different cave-forming mechanisms appear to have operated in the flow field north of Arsia Mons: lava tubes, volcano-tectonic fractures and atypical pit craters. Specific examples can now be targeted by HiRISE and future instruments to ascertain their suitability for exploration and human habitation and to determine what capabilities must be developed to reach them.

\section{ACKNOWLEDGEMENTS}

We thank the THEMIS and HiRISE science teams for supporting this work and targeting the cave entrances described here. Chris Okubo, Timothy Titus, and Lazlo Keszthelyi provided invaluable suggestions and advice.

\section{REFERENCES}

Balch, E.S., 1900, Glacières or Freezing Caverns: Philadelphia, Allen, Lane \& Scott, $337 \mathrm{p}$.

Banerdt, W.B., Golombek, M.P., and Tanaka, K.L., 1992, Stress and tectonics on Mars, in Kieffer, H.H., Jakosky, B.M., Snyder, C.W., and Matthews, H., eds., Mars: Tucson, University of Arizona Press, p. 249-297.

Benson, J.L., Bonev, B.P., James, P.B., Shan, K.J., Cantor, B.A., and Caplinger, M.A., 2003, The seasonal behavior of water ice clouds in the Tharsis and Valles Marineris regions of Mars: Mars Orbiter Camera Observations: Icarus, v. 165, p. 34-52. doi: 10.1016/S00191035(03)00175-1

Benson, J.L., James, P.B., Cantor, B.A., and Remigio, R., 2006, Interannual variability of water ice clouds over major Martian 
volcanoes observed by MOC: Icarus, v. 184, p. 365-371. doi: 10.1016/ j.icarus.2006.03.014.

Bleacher, J.E., Greeley, R., Williams, D.A., Cave, S.R., and Neukum, G., 2007a, Trends in effusive style at the Tharsis Montes, Mars, and implications for the development of the Tharsis province: Journal of Geophysical Research, v. 112, E09005. doi:10.1029/2006JE002873.

Bleacher, J.E., Greeley, R., Williams, D.A., Werner, S.C., Hauber, E., and Neukum, G., 2007b, Olympus Mons, Mars: Inferred changes in late Amazonian aged effusive activity from lava flow mapping of Mars Express High Resolution Stereo Camera data: Journal of Geophysical Research, v. 112, E04003. doi:10.1029/2006JE002826.

Boston, P.J., Spilde, M.N., Northup, D.E., Melim, L.A., Soroka, D.S., Kleina, L.G., Lavoie, K.H., Hose, L.D., Mallory, L.M., Dahm, C.N., Crossey, L.J., and Schelble, R.T., 2001, Cave biosignature suites: Microbes, minerals and Mars: Astrobiology Journal, v. 1, no. 1, p. 25-55. doi:10.1089/153110701750137413.

Boston, P.J., Frederick, R.D., Welch, S.M., Werker, J., Meyer, T.R., Sprungman, B., Hildreth-Werker, V., Thompson, S.L., and Murphy, D.L., 2003, Human utilization of subsurface extraterrestrial environments: Gravitational and Space Biology Bulletin, v. 16, no. 2, p. $121-131$.

Boston, P.J., Frederick, R.D., Welch, S.M., Werker, J., Meyer, T.R., Sprungman, B., Hildreth-Werker, V., and Thompson, S.L., 2004, Extraterrestrial subsurface technology test bed: Human use and scientific value of Martian caves: American Institute of Physics Conference Proceedings, v. 699, p. 1007-1018. doi:10.1063/1.1649667.

Cabrol, N.A., Grin, E.A., and Wynne, J.J., 2009, Detection of caves and cave-bearing geology on Mars: $40^{\text {th }}$ Lunar and Planetary Science Conference, Houston, Texas, Abstract No. 1040.

Calvari, S., and Pinkerton, H., 1999, Lava tube morphology on Etna and evidence for lava flow emplacement mechanisms: Journal of Volcanology and Geothermal Research, v. 90, p. 263-280. doi:10. 1016/S0377-0273(99)00024-4.

Christensen, P.R., Jakosky, B.M., Kieffer, H.H., Malin, M.C., McSween, H.Y., Nealson, K., Mehall, G.L., Silverman, S.H., Ferry, S., and Caplinger, M., 2004, The Thermal Emission Imaging System (THEMIS) for the Mars 2001 Odyssey Mission: Space Science Reviews, v. 110, p. 85-130, doi: 10.1023/B:SPAC.0000021008.16305. 94.

Christensen, P.R., Gorelick, N., Anwar, S., Dickenshied, S., Edwards, C., and Engle, E., 2007, New insights about Mars from the creation and analysis of Mars global datasets: American Geophysical Union Fall Meeting, San Francisco, California, Abstract No. P11E-01.

Coombs, C., and Hawke, R., 1992, A search for intact lava tubes on the Moon: Possible lunar base habitats, in Mendell, W.W., ed., The Second Conference on Lunar Bases and Space Activities of the $21^{\text {st }}$ Century: NASA Conference Publication 3166, v. 1, p. 219-229.

Coons, D., 2010, Caving beneath the Great Crack of Kilauea Volcano: NSS News, v. 68 , no. 12 , p. $8-16$.

COSPAR (Committee on Space Research, World Space Council Planetary Protection Policy), Amended 2011, http://0-science.nasa.gov.iii-server. ualr.edu/media/medialibrary/2011/02/16/Rummel_-_COSPAR_Activities_ to_PPS.pdf.

Cropley, J.B., 1965, Influence of surface conditions on temperatures in large cave systems: Bulletin of the National Speleological Society, v. 27 , p. $1-10$.

Cruikshank, D.P., and Wood, C.A., 1972, Lunar rilles and Hawaiian volcanic features: Possible Analogues: The Moon, v. 3, no. 4, p. $412-447$.

Cushing, G.E., Titus, T.N., Wynne, J.J., and Christensen, P.R., 2007, THEMIS observes possible cave skylights on Mars: Geophysical Research Letters, v. 34, L17201, doi:10.1029/2007GL030709.

Cushing, G.E., Titus, T.N., Jaeger, W.L., Kezthelyi, L.P., McEwen, A.S., and Christensen, P.R., 2008, Continuing study of anomalous pit craters in the Tharsis Region of Mars: New observations from HiRISE and THEMIS, $39^{\text {th }}$ Lunar and Planetary Science Conference, Abstract No. 2447

Cushing, G.E., and Titus, T.N., 2010, Caves on Mars: Candidate sites for astrobiological exploration: Astrobiology Science Conference 2010, Abstract No. 5414.

Daga, A.W., Towarnicki, M.A., Wendel, M.A., and Wendel, W., 1988, Evolving concepts of lunar architecture: The potential of subselene development: Abstracts of the $2^{\text {nd }}$ Lunar Bases and Space Activities of the $21^{\text {st }}$ Century Conference, Lunar \& Planetary Institute, $67 \mathrm{p}$.
Dansgaard, W., Johnsen, S.J., Clausen, H.B., Dahl-Jensen, D., Gundestrup, N.S., Hammer, C.U., Hvidberg, C.S., Steffensen, J.P., Sveinbjörnsdottir, A.E., Jouzel, J., and G. Bond, 1993, Evidence for general instability of past climate from a 250-kyr ice-core record: Nature, v. 364, p. 218-220. doi:10.1038/364218a0.

De Angeles, G., Wilson, J.W., Clowdsley, M.S., Nealy, J.E., Humes, D.H., and Clem, J.M., 2002, Lunar Lava Tube Radiation Safety Analysis: Journal of Radiation Research, v. 43 supplement, p. S41S45. doi:10.1269/jrr.43.S41.

Ferrill, D.A., et al., 2003, Influence of gravity on the geometry of Martian normal faults: $34^{\text {th }}$ Lunar and Planetary Science Conference, Abstract. No. 2050.

Glaze, L.S., Anderson, S.W., Stofan, E.R., Baloga, S., and Smrekar, S.E., 2005, Statistical distribution of tumuli on pahoehoe flow surfaces: Analysis of examples in Hawaii and Iceland and potential applications to lava flows on Mars: Journal of Geophysical Research, v. 110, B08202. doi:10.1029/2004JB003564.

Greeley, R., 1971a, Observations of actively forming lava tubes and associated structures, Hawaii: Modern Geology, v. 2, p. 207-223.

Greeley, R., 1971b, Lava tubes and channels in the Lunar Marius Hills: Earth, Moon, and Planets, v. 3, no. 3, p. 289-314. doi:10.1007/ BF00561842.

Greeley, R., 1972, Additional observations of actively forming lava tubes and associated structures, Hawaii: Modern Geology, v. 3, p. 157-160.

Grin, E.A., Cabrol, N.A., and McKay, C.P., 1998, Caves in the Martian regolith and their significance for exobiology exploration: $29^{\text {th }}$ Lunar and Planetary Science Conference, Abstract No. 1012.

Halliday, W.R., 1954, Ice caves of the United States: The American Caver, Bulletin Sixteen of the National Speleological Society, v. 16, p. 3-28.

Haruyama, J., Hioki, K., Shirao, M., Morota, T., Hiesinger, H., van der Bogert, C.H., Miyamoto, H., Iwasaki, A., Yokota, Y., Ohtake, M., Matsunaga, T., Hara, S., Nakanotani, S., and Pieters, C.M., 2009, Possible lunar lava tube skylight observed by SELENE cameras: Geophysical Research Letters, v. 36, L21206. doi: 10.1029/2009 GL040635.

Head, J.W., and Marchant, D.R., 2003, Cold-based mountain glaciers on Mars: Western Arsia Mons: Geology, v. 31, no. 7, p. 641-644. doi:10.1130/0091-7613(2003)031<0641:CMGOMW>2.0.CO;2.

Helbert, J., Head, J., Marchant, D., Shean, D., and Kreslavsky, M., 2006, First Prospecting for Ice in the Flank Deposit at Arsia Mons: $37^{\text {th }}$ Lunar and Planetary Science Conference, Abstract No. 1371.

Hill, C.A., and Forti, P., 1997, Cave Minerals of the World, second edition: Huntsville, Alabama, National Speological Society, 463 p.

Horz, F., 1985, Lava tubes: Potential shelters for habitats, in Mendell, W.W., ed., Lunar Bases and Space Activities of the $21^{\text {st }}$ Century: Houston, Lunar and Planetary Institute, p. 405-412.

Ingham, K.L., Northup, D., and Welbourn, W.C., 2008, Climate modeling for two lava tube caves at El Malpais National Monument, New Mexico USA, in Espinasa-Pereña, R., and Pint, J., eds., Proceedings of the X, XI, and XII International Symposia on Vulcanospeleology: Austin, Texas, Association for Mexican Cave Studies Bulletin 19, p. 126-131.

Jaeger, W.L., Keszthelyi, L.P., Skinner, J.A., Milazzo, M.P., McEwen, A.S., Titus, T.N., Rosiek, M.R., Galuszka, D.M., HJowington-Kraus, E., Kirk, R.L., and the HiRISE Team, 2010, Emplacement of the youngest flood lava on Mars: A short, turbulent story: Icarus, v. 205, p. 230-243. doi:10.1016/j.icarus.2009.09.011.

Kauahikaua, J., Sherrod, D.R., Cashman, K.V., Heliker, C., Hon, K., Mattox, T.N., and Johnson, J.A., 2003, Hawaiian lava-flow dynamics during the $\mathrm{Pu}^{\prime} \mathrm{u}$ ' $\bar{O}^{\prime} \mathrm{O}-\mathrm{K}$ ūpaianaha eruption: A tale of two decades, in Heliker, C., Swanson, D.A., Takahashi, T.J., eds., The $\mathrm{Pu}^{6} \mathrm{u}$ 'Ō'ō-Kūpaianaha Eruption of Kīlauea Volcano, Hawai'i: The First 20 Years: U.S. Geological Survey Professional Paper 1676, p. 63-87.

Keszthelyi, L., 1995, A preliminary thermal budget for lava tubes on the Earth and planets: Journal of Geophysical Research, v. 100, no. B10, p. 20411-20420. doi:10.1029/95JB01965.

Keszthelyi, L., and Self, S., 1998, Some physical requirements for the emplacement of long basaltic lava flows: Journal of Geophysical Research, v. 103, no. B11, p. 27447-27464. doi:10.1029/98JB00606.

Léveillé, R.J., and Datta, S., 2010, Lava tube caves on Mars-seeking signs of past life: Astrobiology Science Conference 2010: Evolution of Life: Surviving Catastrophes and Extremes on Earth and Beyond, Abstract No. 5344. 
Malin, M.C., Bell III, J.F., Cantor, B.A., Caplinger, M.A., Calvin, W.M., Clancy, R.T., Edgett, K.S., Edwards, L., Haberle, R.M., James, P.B., Lee, S.W., Ravine, M.A., Thomas, P.C., and Wolff, M.J., 2007, Context camera investigation on board the Mars Reconnaissance Orbiter: Journal of Geophysical Research, v. 112, no. E5, E05S04. doi:10.1029/2006JE002808.

Maltagliati, L., Titov, D.V., Encrenaz, T., Melchiorri, R., Forget, F., Garcia-Comas, M., Keller, H., Langevin, Y., and Bibring, J.-P., 2008, Observations of atmospheric water vapor above the Tharsis volcanoes on Mars with the OMEGA/MEX imaging spectrometer: Icarus, v. 194, p. 53-64. doi:10.1016/j.icarus.2007.09.027.

Mazur, P., Barghoorn, E.S., Halvorson, H.O., Jukes, T.H., Kaplan, I.R., and Margulis, L., 1978, Biological implications of the Viking mission to Mars: Space Science Reviews, v. 22, p. 3-34.

McEwen, A.S., Eliason, E.M., Bergstrom, J.W., Bridges, N.T., Hansen, C.J., Delamere, W.A., Grant, J.A., Gulick, V.C., Herkenhoff, K.E., Keszthelyi, L., Kirk, R.L., Mellon, M.T., Squyres, S.W., Thomas, N., and Weitz, C.M., 2007, Mars Reconnaissance Orbiter's High Resolution Imaging Science Experiment (HiRISE): Journal of Geophysical Research, v. 112, no. E5, E05S02. doi:10.1029/ 2005JE002605.

Miyamoto, H., Haruyama, J., Kobayashi, T., Suzuki, K., Okada, T., Nishibori, T., Showman, A., Lorenz, R., Mogi, K., Crown, D.A., Rodriguez, J.A.P., Rokugawa, S., Tokunaga, T., and Masumoto, K., 2005, Mapping the structure and depth of lava tubes using ground penetrating radar: Geophysical Research Letters, v. 32, L21316. doi:10.1029/2005GL024159.

Mouginis-Mark, P.J., 1990, Recent water release in the Tharsis Region of Mars: Icarus, v. 84, p. 362-373. doi:10.1016/0019-1035(90)900 44-A.

Mouginis-Mark, P.J., and Christensen, P.R., 2005, New Observations of volcanic features on Mars from the THEMIS instrument: Journal of Geophysical Research, v. 110, E08007. doi:10.1029/2005 JE002421.

NCRP, 2001, Radiation Protection Guidance for Activities in Low-Earth Orbit: National Council on Radiation Protection and Measurements, NCRP Publication No. N.132.

Neukum, G., and Hiller, K., 1981, Martian Ages: Journal of Geophysical Research, v. 86, no. B4, p. 3097-3121. doi:10.1029/JB086iB04p03097.

Noe Dobrea, E.Z., and Bell III, J.F., 2005, TES spectroscopic identification of a region of persistent water ice on the flanks of Arsia Mons Volcano, Mars: Journal of Geophysical Research, v. 110, E05002. doi:10.1029/2003JE002221.
Oberbeck, V.R., Quaide, W.L., and Greeley, R., 1969, On the origin of Lunar sinuous rilles: Modern Geology, v. 1, p. 75-80.

Okubo, C.H., and Martel, S.J., 1998, Pit crater formation on Kilauea volcano, Hawaii: Journal of Volcanology and Geothermal Research, v. 86, p. 1-18. doi:10.1016/S0377-0273(98)00070-5.

Pflitsch, A., and Piasecki, J., 2003, Detection of an airflow system in Niedzwiedzia (Bear) Cave, Kletno, Poland: Journal of Cave and Karst Studies, v. 65 , p. 160-173.

Phillips, R.J., Sleep, N.H., and Barendt, W.B., 1990, Permanent uplift in magmatic systems with application to the Tharsis Region of Mars: Journal of Geophysical Research, v. 95, no. B4, p. 5089-5100. doi:10.1029/JB095iB04p05089.

Plescia, J.B., and Saunders, R.S., 1979, Styles of faulting and tectonics of the Tharsis region: $10^{\text {th }}$ Lunar and Planetary Science Conference, Abstract, p. 986-988.

Sakimoto, S.E.H., Crisp, J., and Baloga, S.M., 1997, Eruption constraints on tube-fed planetary lava flows: Journal of Geophysical Research, v. 102, no. E3, p. 6597-6613. doi:10.1029/97JE00069.

Self, S., Keszthelyi, L.P., and Thordarson, T., 1998, The importance of pāhoehoe: Annual Review of Earth and Planetary Sciences, v. 26, p. 81-110.

Shean, D.E., Head, J.W. III, Fastook, J.L., and Marchant, D.R., 2007, Recent glaciation at high elevations on Arsia Mons, Mars: Implications for the formation and evolution of large tropical mountain glaciers: Journal of Geophysical Research, v. 112, E03004. doi: 10.1029/2006JE002761.

Wentworth, C.K., and Macdonald, G.A., 1953, Structures and Forms of Basaltic Rocks in Hawaii: Washington D.C., Government Printing Office, U.S. Geological Survey Bulletin 994, 98 p.

Werner, S.C., 2005, Major aspects of the chronostratigraphy and geologic evolutionary history of Mars [Ph.D. dissertation]: Berlin, Frie University, http://www.diss.fu-berlin.de/2006/33/index.html, 74 p.

Williams, K.E., McKay, C.P., Toon, O.B., and Head, J.W., 2010, Do ice caves exist on Mars?: Icarus, v. 209, p. 358-368. doi:10.1016/j.icarus. 2010.03.039.

Wynne, J.J., Titus, T.N., and Chong Diaz, G., 2008, On developing thermal cave detection techniques for Earth, the Moon and Mars: Earth and Planetary Science Letters, v. 272, p. 240-250. doi:10.1016/ j.eps1.2008.04.037.

Zuber, M.T., Smith, D.E., Solomon, S.C., Muhleman, D.O., Head, J.W., Garvin, J.B., Alshire, J.B., and Bufton, J.L., 1992, The Mars Observer laser altimeter investigation: Journal of Geophysical Research, v. 97, no. E5, p. 7781-7797. doi:10.1029/92JE00 341 . 